\title{
Sex and Gender in the European Union
}

\author{
Arántzazu Vicente-Palacio \\ University Jaume I-Castellón
}

The ECJ Judgment (Court of Justice of European Union) of 26 July 2018 (M.B. Case) declares the discriminatory nature of a national (British) regulation that requires married transgender people to have their marriage annulled to gain full legal recognition of their gender change, as a condition for access to a retirement pension established by national law for people who have changed gender. This judgment is made to Directive 79/7/EEC of 19 December 1978 on the progressive implementation of the principle of equal treatment for men and women in matters of social security.

This work analyzes this judicial pronouncement, placing it in the set of the community jurisprudence which dealt with the consequences of the gender change from the community regulations of a socio-laboral nature. It points out the Spanish legal regulation concerning gender change and consequences in terms of social security. The work proves that in many cases wherein, despite the sex-gender differentiation, both terms are used in the same sense. The paper advocates a "de-gendered" and "de-gendering" law indicated by the author in the final epilogue.

Keywords: intersexualism, transgender, social security, gender identity, European court of justice, degendered law, lgbti

\section{THE JUDGMENT OF THE COURT OF JUSTICE OF 26 JUNE 2018 (MB V SECRETARY OF STATE FOR WORK AND PENSIONS CASE) ${ }^{2}$}

"(...) Gender is a different matter. It is a more nebulous entity, however you conceive it. It lives in cavities. It transcends the body. (...) So I do not mind my continuing ambiguity. I have lived the life of man, I live now the life of woman, and one day perhaps I shall transcend both (...). There is no norm, no criterion, and perhaps no explanation (...)”.

$$
\text { Jan Morris “Conundrum”, } 1974^{1}
$$

\section{Factual Background and Applicable National (British) Regulations}

The ECJ Judgment of 28 June 2018 resolves a preliminary request submitted by the Supreme Court of the United Kingdom. After the apparent simplicity of the request posed (Is the requirement of not being married contrary to the prohibition of discrimination based on sex in matters of social security set out in Directive 79/7/EEC?), the Court of Justice again addressed the discrimination of intersexual/transgender persons, although from the limited scope to which its jurisdiction extends invoked by the national court: Directive 79/7/EEC of 19 December 1978 on the progressive implementation of the principle of equal treatment for men and women in matters of social security. I am deliberately pointing out the limited scope 
of the rules in which the request for a preliminary ruling is raised and, consequently, the arguments and the judgment, a subject to which I shall have occasion to return later on.

The ECJ has already had occasion to address discrimination against intersexual/transgender people in the UK in the field of employment contracts $(S v P \text { case and Cornwall case })^{3}$ and also in the field of social security on several occasions (Richards case $e^{5}$ and $K B$ case $^{6}$ ). It is precisely in the first judgment that the Gender Reassignment Regulations (1999) were promulgated, amending the Sex Discrimination Act (1975) to include within its scope cases of direct discrimination against any employee based on gender change. Prior to this reform, this regulation maintained a strictly binary definition of sex/gender categories (male/female) and the prohibition of any discrimination -direct or indirect- does not take into account discrimination that might result from a change in gender, since British law only recognizes these two categories (Birth and Death Registration Act, 1953) ${ }^{7}$.

The Richards case concerned the legal impossibility for the applicant to obtain legal recognition of the change of gender at the time she submitted her application for a retirement pension at the age set by British law for women (60 years). The retirement age for men is set at 65 . When she underwent gender reassignment surgery (3 May 2001), it was not possible under national legislation to change the gender on her birth certificate (male), and the British Social Security Administration refused to grant her a pension because she had not yet reached the retirement age applicable to the legally recognized sex (male). By the time the question was referred to the $\mathrm{ECJ}_{8}$, the Gender Recognition Act (2004) had already been passed but had not yet entered into force. According to this norm, those persons who had already changed their gender, or who were planning a surgical operation of this type, could request a «gender recognition certificate», which would imply full recognition of their gender change when it became definitive.

The Panel was required to grant this (final) certificate if the applicant met the following requirements: a) Has or has had gender dysphoria; b) Has lived in the acquired gender throughout the period of two years ending with the date on which the application is made; c) Intends to continue to live in the acquired gender until death, and finally, although the Richards judgment does not mention it because it was irrelevant to the question posed at the time, that (d) In the event that the applicant was previously married, the application for the annulment of the marriage, given that, at that time, the applicable national legislation only admitted marriage between a man and a woman (Matrimonial Causes Act, 1973). In addition, it had to meet certain evidentiary requirements: a report prepared by two medical practitioners or by a medical practitioner and a psychologist. It is important to point out -later we will return to this issue- that this regulation does not condition the recognition of gender change to the surgical operation of "gender reassignment" although it does maintain the pathologizing conception of gender "dysphoria".

It is on the fourth requirement mentioned above that the British Supreme Court is now seeking a pronouncement on its compliance with Directive 79/7/EEC. It should be noted that once again the British legal regulation has changed during the procedural iter. The Marriage Same Sex Couples (2013) ${ }^{10}$, in addition to allowing marriage between persons of the same gender, amended the Gender Recognition Act (2004) in order to replace the requirement of marriage annulment by the consent of the partner if the transgender person was previously married.

The factual background of the main litigation is simple. MB was born in 1948 with the male sex assigned at birth and married a woman in 1974. In 1991 she began to live her life as a woman and in 1995 she underwent gender reassignment surgery. However, $\mathrm{MB}$ was not able to obtain a gender change recognition certificate when she refused to apply for an annulment of her marriage as both she and her wife wished to continue with this marital situation. This did not prevent $\mathrm{MB}$ from applying for the recognition of the right to the retirement pension (Class A) when she reached 60 years of age (2008), since this is the age foreseen for the access to this retirement pension for women born before April 6, 1950. Males born before December 6, 1953 are not eligible for retirement until age 65 (Social Security Contributions and Benefits Act, 1992; Pensions Act, 1995).

The national legal regulations applicable at the time of the main dispute have already been noted. Marital status conditions the definitive recognition of the change of gender in national legislation to the application for annulment of the marriage if the transgender person was married before the change of gender, given that, at that time, the applicable national legislation only admitted marriage between a man 
and a woman (Matrimonial Causes Act, 1973). Only this recognition certificate constituted the acquired gender identity valid for all purposes. Specifically, with regard to the right to receive a public retirement pension, the law provides that the sex of the applicant must always be that of their acquired gender.

\section{Positions of the Parties and Opinion of the Advocate General (From a Restrictive Perspective)}

The applicant believes that the requirement for the annulment of the previous marriage constitutes discrimination arising from gender reassignment because it is not required of cisgender persons, who are eligible for the retirement pension regardless of their marital status. On the other hand, the British Ministry of Work and Pensions invokes the Community jurisprudence (Richards case) according to which it is up to the Member States to establish the requirements for the legal recognition of the change of gender of a person, being valid that, in addition to social, physical and psychological criteria, requirements concerning the marital status can be established. It also invokes the doctrine of the European Court of Human Rights (Cases Parry v United Kingdom and R and F v United Kingdom ${ }^{11}$ and Hämäläinen Judgment ${ }^{12}$ ). According to this Court, making the recognition of a change of gender conditional on the prior annulment of the marriage is not contrary to the European Convention on Human Rights since this rule does not oblige Member States to recognize marriage between persons of the same gender. For the British Ministry, this is a condition that aims to "maintain the traditional concept of marriage as a union between a man and $a$ woman".

As the Advocate General rightly points out in his Opinion, each party to the proceedings has formulated its arguments from different perspectives.

The applicant for the retirement pension questions only the compliance of this requirement with the prohibition of discrimination on ground of sex set out in Directive 79/7/EEC. It is from this same restrictive perspective that the Community Court has decided the request for a preliminary ruling, since it is defined in these terms by the British Supreme Court. The ECJ thus dismisses the broad option chosen by the British Government, which prefers to situate the request in the context of the protection of fundamental rights and, specifically, whether it is compatible with the fundamental right to private and family life and the right to marriage for a Member State: a) to refuse to allow marriage between persons of the same sex, and consequently; b) to refuse to recognize a change of gender if it entails two persons of the same gender being married in a valid marriage (between persons of the same gender). The Advocate General also supports the option of the restrictive perspective both because this is the perspective from which the referred request for a preliminary ruling arises and also because of two factual considerations which the national court points out: a) that the requirement of marriage annulment is required exclusively of persons who have changed gender; b) that the requirement of not being married is required in addition to the criteria of a physical, social and psychological nature.

The broad perspective advocated by the British government is deliberate because focusing the core of the debate on marital status leaves the controversial issue outside the jurisdiction of the ECJ. As the British Government itself states in its considerations, invoking the doctrine of the ECJ, the setting of the requirements for obtaining recognition of gender change is the competence of the Member States (Richards case). Similarly, the Member States are entitled to regulate public policy objectives, considering that any requisite aimed at preventing marriages between persons of the same sex is legitimate. It further considers that the elimination of the requirement of not being married for the sole purpose of interpreting Directive 79/7/EC would undermine the coherence of the national legal system on marital status and gender change and that the European Court of Human Rights has held that the requirement of not being married is in conformity with the European Convention on Human Rights.

The Advocate General analyzes the arguments of both parties in detail, developing a doctrine -although without legal effects- of great interest for the legal interpretation of national systems in the context of Union Law. However, the Advocate General is in favor of resolving the question within the restricted perspective, since this is the one adopted by the national court when it comes to the preliminary ruling. It concludes from this approach that the requirement that intersexual/transgender persons be unmarried in order to obtain a public retirement pension is discriminatory. 


\section{Argumentation and Court Ruling}

From the restrictive point of view set out above, the judgment resolves the question referred for a preliminary ruling that it opposes Directive 76/7/EEC where national legislation requires a person who has undergone a gender change to satisfy not only physical, social and psychological criteria but also the condition of not being married to a person of their acquired gender, in order to be eligible for a State pension when they reach the legal retirement age for persons of their acquired gender.

The Court of Justice has progressively unraveled the various legal arguments on which its ruling is based in the light of the Directive invoked and the different (and abundant) Community case law. In order to simplify their presentation, these arguments are summarized below:

a) With regard to marital status, the principle of non-discrimination on ground of sex and the prohibition of discrimination on ground of sex:

- Although Union law does not affect the competence of Member States with regard to the civil status of individuals, Member States must respect Union Law when exercising this competence, in particular the provisions relating to the principle of nondiscrimination [ECJ Judgment of 27-4-2006 (Richards case) ${ }^{13}$; ECJ Judgment of 1-42008 (Maruko case) $)^{14}$; ECJ Judgment of 5-6-2018 (Coman case) $]^{15}$.

- A national regulation that makes obtaining a pension contingent on a marital status requirement cannot be exempted from compliance with the principle of nondiscrimination on ground of sex (art. $157 \mathrm{TFEU}$ ) in the area of workers' compensation [ECJ Judgment of 7-1-2004 (KB case)] ${ }^{16}$. Consequently, when exercising their powers in the area of marital status, Member States must comply with art. 4.1 of Directive $79 / 7 / \mathrm{EEC}$, which applies the principle of non-discrimination in the area of social security. This prohibition of discrimination is particularly preached with respect to the conditions of access to legal systems that ensure protection against the risks of old age, as is the case in question.

b) On the concept of sex discrimination:

- It constitutes direct discrimination on ground of sex if a person is, has been or could be treated in a less favorable manner than another person in a comparable situation (Directive 2006/54/EU) and this concept should also be understood in the context of Directive 79/7/EEC.

- In view of the purpose and nature of the rights it seeks to protect, Directive 79/7/EEC must also apply to discrimination resulting from a change in the gender of the person concerned.

- Although it is for the Member States to determine the requirements for legal recognition of the change of gender of a person, it should be stated that, for the purposes of applying Directive 79/7/EC, persons who have lived for a significant period as persons of a gender other than their sex assigned at birth and who have undergone a gender reassignment operation should be considered as having changed gender.

- In so far as the controversial national legislation in question makes the receipt of a State retirement pension at the age corresponding to the acquired gender of the person who has undergone a gender reassignment subject to the annulment of any marriage concluded before the gender reassignment and does not require the married person to retain their sex assigned at birth and to be married, that national legislation confers less favorable treatment on grounds of gender, which is capable of constituting direct discrimination within the meaning of art 4.1 of Directive 79/7. The final conclusion will depend on the comparability of the two situations.

c) On the comparability of the situation of a transgender person and a cisgender person, both married: 
- The requirement of comparability of situations does not demand that the situations be identical but only that they be analogous (ECJ Judgment 10-5-2011, Römer case) ${ }^{17}$; ECJ Judgment 19-7-2017; Abercrombie \& Fitch case (Italy) ${ }^{18}$

- The comparable nature of the situations must not be assessed in a global and abstract manner but in a specific and concrete manner, taking into account all the elements that characterize them, especially in the light of the object and purpose of the national legislation that establishes the disputed distinction and, where appropriate, of the principles and objectives of the field to which that national legislation belongs (ECJ Judgment of 16-12-2018, Case of Arcelor Atlantique et Lorraine and others ${ }^{19}$; ECJ Judgment of 15-7-2015, Case of Chez Razpredeleine v Bulgaria ${ }^{20}$; and ECJ Judgment of 9 March 2017, Milkova case ${ }^{21}$ ).

- In the light of the national legislation, the retirement pension in question is granted to all staff who have reached the prescribed age and have contributed sufficiently to the public pension scheme in the United Kingdom. This scheme (...) protects against the risk of old age (...) irrespective of marital status.

- In view of the object and requirements for granting the pension, the situation of a person who has changed gender after marriage is comparable to the situation of a staff member who has retained her sex assigned at birth and is married.

- The different marital status invoked by the British government to deny the comparability of situations is tantamount to making marital status a decisive element in the comparability of situations even though this circumstance is not in itself relevant to the granting of the state retirement pension.

- The purpose that the British government attributes to marriage annulment (to avoid marriages between people of the same sex) is alien to the retirement pension system.

- The jurisprudence of the European Court of Human Rights invoked by the British Government is not applicable. The ECHR Judgment of 16 July 2014 (Hämäläinen v. Finland), which also dealt with the legal comparability between a married cisgender person and a married transgender person, did not apply to Finnish national legislation on the legal recognition of gender change in matters of marital status.

d) With regard to any exceptions to the prohibition of direct discrimination on ground of sex provided for in the Directive (art. 7)

- Preventing the existence of marriages between persons of the same gender because national law did not allow them at the time of the main proceedings cannot be construed as a ground for derogation from the prohibition of direct discrimination on ground of sex. The cases in which an exception may be made to the direct prohibition are listed exhaustively in the Directive.

- Although the Directive allows Member States to exclude from their scope of application the fixing of the retirement age for the granting of old-age and retirement pensions, and the consequences thereof for other benefits [art. 7.1.a)], this provision does not allow Member States to treat differently a person who has changed gender after marriage and a person who has retained his or her sex assigned at birth and is married, as regards the age determining the receipt of a State retirement pension.

\section{Special Reference to the Opinion of the Advocate General (From a Broad Perspective)}

It has already been pointed out above that the Advocate General raises as a preliminary point the possibility of approaching the request at issue in the main proceedings from two different perspectives, advocating in this case the appropriateness of the restrictive approach, in the light of the terms of the request referred by the Supreme Court for a preliminary ruling. However, it does not wish to miss the opportunity to address the limits of the Member States in regulating those matters which, although they fall within the 
scope of national jurisdiction, may constitute an obstacle to the effectiveness of the prohibition of discrimination on ground of sex.

Despite its lack of direct legal effect, the answers to the questions it raises acquire special significance in an era in which not all Member States seem to be aligned with the basic social principles of the European Union and in which (unfortunately) we are witnessing the landing in the representative bodies of popular sovereignty of political parties contrary to these social principles.

As has been shown, a large part of the UK Government's allegations are based on the freedom recognized by the ECJ itself (also by the ECHR), which assists Member States in regulating the requirements for recognition of gender change and the regulation of the marital status of individuals. It is not so much interesting now to look at the specific case analyzed when reproducing its considerations (or conclusions) in relation to the limits of national law in order to establish those indispensable preconditions that condition access to the old-age pension. Therefore, for the sake of brevity, neither will the response to the government's allegations regarding the breach of the coherence of the legal system that would result from the non-application of this requirement exclusively for the purposes of access to retirement pensions be reproduced, nor will the allegation regarding the conformity of this requirement with the jurisprudence of the European Court of Human Rights, since the cases examined at that venue dealt with the right to family life (art. 7 ECHR) and on the right to marry (art. 9 ECHR) and not on the prohibition of discrimination on ground of sex in the field of social security.

The Advocate General's conclusions from this broad perspective are as follows:

a) National legislation which, by not acknowledging the acquired gender identity of transgender people, prevents a transgender person from fulfilling one of the conditions for the enjoyment of a right protected by (EU) law must, in principle, be considered incompatible with (EU) Law.

b) The opposite approach would make the scope of application of Union law in relation to the prohibition of discrimination on ground of sex entirely dependent on the various requirements laid down at national level. The enjoyment of the rights conferred by Union Law would depend on the unrestricted discretion of the Member States. These requirements would not only regulate technical matters of a physical, medical and psychosocial nature, but would also be designed to protect morals or values. Unlimited discretion in this respect would mean running the risk that discrimination based on gender change, prohibited by the Directive, would come back through the back door in the form of preconditions or requirements associated with recognition of (marital) status regardless of its content.

c) Where and how should the line be drawn between "acceptable" requirements (those excluded from any review) and "unacceptable" requirements (those subject to review)? Requirements considered "acceptable" per se and in an abstract manner could, in certain factual or legal contexts, lead to completely unacceptable consequences.

d) It should be borne in mind that the logic according to which certain requirements for gender change would be excluded from any review would also fail to take into account the dynamic nature of the recognition of gender as a process. Because of the dynamic nature inherent in transgenderism, protection is necessary not only when full recognition of gender change has already been obtained but also (and sometimes very particularly) with respect to the procedures for obtaining it.

e) Although the requirements for the recognition of gender change remain within the competence of the Member States, this does not mean (...) that they act completely outside the scope of Union Law and can therefore escape any kind of scrutiny. (...) In exercising that competence, Member States must respect Union Law, in particular the provisions relating to the principle of non-discrimination.

f) There is no general, unavoidable rule for determining the stage or moment when a transgender person is covered by the right to equal treatment and the prohibition of discrimination under Union Law. Each individual case must be analyzed in the light of the particular situation and the request referred for a preliminary ruling. 
g) In exercising their powers in matters of civil status, Member States must comply with Union Law, even if civil status and the benefits deriving therefrom fall within the competence of the Member States. Union Law does not restrict this competence (Parris case ${ }^{22}$ ). Member States are free to allow or not allow marriage between couples of the same gender or, if they so wish, to provide for an alternative form of legal recognition of persons of the same gender. The possible incompatibility (of the requirement of marriage annulment) with Directive 79/7/EC does not imply an obligation for Member States to recognize marriage between persons of the same gender. It would only be necessary to make access to the benefit in question independent of this requirement, which does not mean that it cannot continue to be integrated into national legislation, but it could not be applied as a precondition for access to benefits (old age) not related to marital status.

The Advocate General concludes with five final observations. Of these, the third is worth noting: "(...) This case deals with a unique and singular reality, difficult to fit into the traditional binary divisions on which the prohibition of discrimination on ground of sex hinges (...). It refers to a complex human reality that the various legal systems have had difficulty reflecting over time and in which the personal situation of individuals is profoundly affected by continuous legislative changes (...)".

\section{A BRIEF NOTE ON GENDER CHANGE IN SPANISH LAW AND ITS POSSIBLE IMPACT ON SOCIAL SECURITY}

The Spanish regulations on gender change are characterized by their dispersion and fragmentation. In matters of civil legislation, the State retains exclusive jurisdiction, which extends - in any case and without exception - to the rules relating to legal-civil relations concerning forms of marriage and the organization of public registers and instruments (art. 149.1.8 of the Spanish Constitution). The Autonomous Communities with their own civil, foral or special Law maintain the competence for their conservation, modification and development, but without affecting the exclusive state competence mentioned.

In use of this exclusive competence, the promulgation of Law 13/2005, of July 1, which modifies the Civil Code in the matter of the right to contract marriage, meant that the requirements and effects of the marriage were equalized regardless of the gender of the contracting parties (art. 44 Civil Code). For its part, Law 3/2007 of March 15, 2007, which regulates the rectification of the gender of persons in the registry ${ }^{23}$ (hereinafter GRRL), recognized the possibility of rectifying the sex of the birth certificate through government records in cases of gender dysphoria (art. 93). This possibility constituted a new exception to the general rule that attributed this possibility exclusively to the courts by means of a final judgment (art. 92 GRRL), requiring then and now the concurrence of the following requirements (arts. 1 and 4 GRRL) ${ }^{24}$.

a) The legitimacy to request the rectification of the registry is the exclusive responsibility of the person concerned, of Spanish nationality and of legal age ${ }^{25}$.

b) The applicant must certify that they have been diagnosed with gender dysphoria by means of a report from a medical practitioner or clinical psychologist who is a member of the Spanish Association of Medical Doctors or whose qualifications have been recognized or approved in Spain. These reports must make express reference to the existence of this discordance between sex and gender; the stability and persistence of this discordance and the absence of personality disorders.

c) The applicant must also provide evidence that they have received medical treatment for at least two years in order to adjust their physical characteristics to those of their gender identity. This compliance is accredited by means of a report from the medical practitioner under whose direction the treatment was carried out or, failing that, by a report from a specialized forensic doctor.

The GRRL expressly excludes the need for medical treatment to include gender reassignment surgery. It also excludes the requirement for medical treatment when there are health or age reasons that make it impossible to follow up on the treatment and medical certification of such circumstances is provided. 
Gender reassignment surgery is no longer an essential requirement for the legal recognition of gender identity as reflected in the change in the registry. The fundamental rights of transgender people are thus respected, who may or may not wish to undergo gender reassignment surgery and who may or may not have the economic possibility of doing so. It should be remembered that gender reassignment surgery is still not included in the National Health Service's Common Portfolio of Services ${ }^{26}$, although it is in the Portfolio of Services of many Autonomous Communities. But it is even more important in that it represents a break with the traditional binarism of sex and gender, which does not correctly reflect the reality of gender identity and in which community regulation in matters of equality based on gender still remains anchored, despite the laudable effort of the ECJ to overcome this outdated conception by including people who have undergone a gender change in the area of direct discrimination under Directive 79/7/EC. As has been pointed out, the Advocate General also refers to this binarism as an element that characterizes the Community regulation on the prohibition of discrimination on ground of sex.

Some Autonomous Communities have specific regulations not only in the area of health care but specifically in the regulation of gender identity ${ }^{27}$. These Autonomous Community regulations, in general, address gender identity from a much broader and neutral ("depathologizing") perspective than the state regulations, restricted as we have seen to the modification of sex in cases of gender "dysphoria" and, subjectively, restricted to persons of Spanish nationality and of legal age. With regard to the public financing of the medical treatments required for the modification of the registry, at present, Andalusia, the Balearic Islands, Catalonia, the Canary Islands, Castile-La Mancha, the Community of Valencia, Extremadura, Galicia, Murcia, Navarre and the Basque Country finance gender reassignment surgery (genitoplasties and breast surgery) and hormonal treatments before and after this possible surgery and have some kind of Reference Center, Service or Unit (RCSU). These RCSUs must meet certain requirements common to the entire National Health System; these criteria are agreed upon by the Interterritorial Council of the National Health Service ${ }^{28}$. Of special significance is the fact that some of them consider gender identity from a broader perspective (in varying degrees) and one that standardizes the complexity of gender identity, including all the dimensions involved in the free development of gender identity: Andalusia ${ }^{29}$, the Canary Islands ${ }^{30}$, Catalonia ${ }^{31}$, Extremadura ${ }^{32}$, Galicia ${ }^{33}$, the Balearic Islands ${ }^{34}$, Madrid ${ }^{35}$, Murcia ${ }^{36}$, Navarra $^{37}$, the Basque Country ${ }^{38}$ and the Valencian Community 39 . This comprehensive approach also includes intersexual or transgender minors, recognizing their right to comprehensive care, for which measures are also provided in the educational and social-health fields. At the state level, there are also parliamentary initiatives that adopt a comprehensive approach focused on the self-determination and expression of gender identity ${ }^{40}$.

The restricted consideration in State Law of the complex reality of gender identity to mere transgenderism raises important problems in the field of Social Security, given the exclusive competence of the State in this area (art. 149.1.17 ${ }^{\circ} \mathrm{EC}$ ). We already have a doctrine from the Constitutional Court declaring the unconstitutionality of the integration of the concept of couples by reference to the regional regulations of the Autonomous Communities with their own civil law for the purposes of widowhood pensions (STC 40/2014, March 11).

Although in Spain there is a uniform age -from the gender/sex perspective- for access to a retirement pension, there are some provisions that give different treatment to men and women in the social security system. These are provisions that, in general, can be classified as positive action measures for women, but whose application to intersexual and transgender people may give rise to legal problems.

The GRRL gives constitutive effects to the administrative resolution of the gender rectification from its inscription in the Civil Registry, enabling the person to exercise all the rights inherent to their acquired condition, decreeing the maintenance of the rights and legal obligations that may correspond to the person prior to the inscription of the registry change (art. 5 GRRL). In terms of strict ordinary law, the registered sex on the date of the causal event is the determinant of the application of the corresponding regulations. However, this solution may be questionable in terms of constitutionality, as the judgment of reasonableness and proportionality that justifies the existence of such gender-based differentiations comes into play.

By way of example only: Is the fictitious contribution provided for in art. 235 of the TRLGSS (Texto Refundido de la Ley General de Seguridad Social or Consolidated Text of the General Social Security Act) 
applicable to a person who, meeting the requirements for biological maternity, was a man at the time of the event causing retirement or permanent disability? Does the calculation of compulsory military service apply to the man who performed it and subsequently changed gender? The application of the maternity allowance provided for in art. 60 of the TRLGSS also raises doubts from this same perspective because the application of the constitutive effect in relation to the date of the event causing it may determine consequences that do not converge with the purpose of the measure. And as I have already pointed out on another occasion ${ }^{41}$, the requirement of common children as a criterion for attributing rights in the field of the regulation of the widow's or widower's pension raises well-founded doubts of constitutionality that have not yet been raised before the Constitutional Court, although we already have judicial pronouncements in similar situations ${ }^{42}$ that may allow us to venture a judgement in relation to the discriminatory nature of certain regulatory provisions if they were to be raised.

\section{BRIEF REFLECTION (EPILOGUE)}

Although its doctrine is important, the ECJ Judgment of July 26, 2018 (M.B. Case) reveals a certain narrowness of the Community regulations regarding discrimination on ground of sex and/or gender. It is true that the inclusion in the subjective ambit of the prohibition of discrimination on ground of sex (in this case, in the field of social security) of persons who have changed gender constitutes positive news and is proof of the value of the interpretative role of the ECJ. But the reading of the ruling also highlights the outdated and obsolete nature of the binarism adopted by the community instances, a reflection of an overcome feminism. It is also a good example of the false modernity that is hidden in many cases in the (only apparently) disjunctive use of the sex/gender binomial when, in reality, it continues to be used in a univocal sense, equating biological sex (even if reassigned) with gender (external manifestation according to the social patterns assigned to the sexual categories). In the same ECJ Judgment, both concepts are used as synonyms, equating sex and gender. It is true that, as we have seen, the British regulations - also the Spanish ones - do not require the (final) surgical intervention of gender reassignment for the registry modification of the change of sex (which is the biological reality), therefore, it could be considered that they do differentiate between sex and gender, but they continue to consider "gender" in exclusively binary terms (male/female) and by continuing to use them as a differentiating element in the normative it perpetuates the social discrimination of gender.

The above statement does not intend to question -quite the opposite- affirmative action measures aimed at (normatively) compensating social discrimination on ground of sex derived, to a large extent, from gender, when the justification is objective and reasonable, and it is so when they are arbitrated to correct situations of real and effective inequality, but it would be desirable for the future -and from the immediate present- to subject public action, especially normative action, to a "(de)gendering" judgment ${ }^{43}$. Despite its apparent advantageous, compensatory or balancing character, does the action and/or measure contribute to perpetuating gender stereotypes by further deepening real discrimination?

Definitely, as far as possible, it is time to advocate for "de-gendered" and "de-gendering" Law: a legal system that, aware of the effective social discrimination on ground of sex, knows how to articulate - in all areas - measures that disrupt the gender roles that still persist in society and that are responsible for the different fate adjudicated according to the current reductionist sexual binarism.

\section{ENDNOTES}

1. MORRIS, Jan, "Conundrum", London (Faber and Faber), 1974. In this work, the author (Sommerset, 1926), an acclaimed English writer and journalist, relates in her own flesh her change of gender (from a masculine sex assigned at birth) in order to acquire the gender identified as her own (feminine) from an early age. During her time as a man, James Morrison was a writer, journalist and soldier, the latter of which she had to abandon in order to explore her sexual identity because it was not "compatible" with her acquired gender. On a personal note, Jan Morris, had to divorce her wife -to whom she had been married as a man since 1946 and with whom she had five children- in order to obtain legal recognition of her gender change. The recognition 
of civil unions for people of the same gender (2008) allowed her to re-formalize the relationship with her wife, from whom he never separated and who throughout her life supported her in the search for her gender identity. In 1960 (as a man) she began hormonal treatment and in 1972 she underwent a surgical operation in Casablanca.

2. Case $\mathrm{C}-451 / 16$

3. Case $\mathrm{C}-13 / 94$

4. A. VICENTE- PALACIO, "Transexualidad y contrato de trabajo. Breves reflexiones a propósito de la STJE de 30-4-1996 (Transsexuality and employment contract. Brief reflections on the ECJ Judgment of 304-)", (S contra P. y Cornwall County Council), Tribuna Social n ${ }^{\circ}$ 66, 1996.

5. ECJ Judgment de 27-4-2006 (Richards case); Case C-423-04.

6. ECJ Judgment de 7-1-2004 (KB case); Case C-117/01.

7. The birth certificate could only be changed on record in the event of a transcription error or material mistake.

8. Date of entry into the ECJ: October 4, 2004

9. 1-7-2004 (Effective Date: 4-4-2005)

10. Effective Date: $10-12-2014$.

11. ECHR Decisions of 28 November 2006.

12. ECJ Judgment of 16-7-2014.

13. C- $-423 / 04$

14. $\mathrm{C}-267 / 06$

15. C-673/16

16. $\mathrm{C}-117 / 01$

17. $\mathrm{C}-147 / 08$

18. $\mathrm{C}-144 / 16$

19. $\mathrm{C}-127 / 07$

20. $\mathrm{C}-83 / 14$

21. C-406/15

22. ECJ Judgment of 24-11-2016 (Parris case). (C-443/2015).

23. By amending the Law of 8 June 1957 on the Civil Registry.

24. The unique transitory disposition exonerates from the accreditation of requirements for the rectification of the sex registry to the person who, by means of a report of a collegiate medical practitioner or certificate of the medical practitioner of the Civil Registry, accredits to have been submitted to surgery of gender reassignment before the entry into force of the law.

25. The Plenary Session of the Constitutional Court, by Ruling of 10 May 2016, has admitted the Question of Unconstitutionality No. 1595-2016 raised by the First Civil Chamber of the Supreme Court, in Appeal No. 1583-2015, in relation to article 1 of Law 3/2007, of 15 March, regulating the rectification of the mention of the sex of persons in the registry, insofar as it only recognizes the right of adults to request the rectification of the mention of the sex and name in the registry, due to the possible violation of articles 15, 18.1 and 43.1, in relation to article 10.1 EC. («S.O.G..»19 may).

26. Royal Decree 1030/2006, of 15 September, establishing the common services portfolio of the National Health System and the procedure for updating it.

27. See on regional regulations, ALVENTOSA DEL RIO, Josefina, "La regulación de la identidad de género en las Comunidades Autónomas", Boletín del Instituto de Derecho Iberoamericano, 3-4-2015 (https://idibe org/cuestiones-de-interes-juridico/la-regulacion-de-la-identidad-de-genero-en-lascomunidades-autonomas/; Accessed on: 6-12-2018)

28. https://www.mscbs.gob.es/profesionales/CentrosDeReferencia/docs/Fesp/Fesp24.pdf (in Spanish).

29. Law $2 / 2014$, July 8 , comprehensive for non-discrimination on the basis of gender identity and recognition of the rights of transgender people in Andalusia; Law 8/2017, December 28, to guarantee the rights, equal treatment and non-discrimination of LGBT people and their families in Andalusia.

30. Law $8 / 2014$ of 28 October on non-discrimination on the basis of gender identity and recognition of the rights of transsexual persons.

31. Law 11/2014 of October 10 to guarantee the rights of lesbians, gays, bisexuals, transgender and intersex people and to eradicate homophobia, biphobia and transphobia.

32. Law 12/2015 of 8 April on social equality of lesbians, gays, bisexuals, transsexuals, transgenders and intersexuals and on public policies against discrimination based on sexual orientation and gender identity in the Autonomous Community of Extremadura 
Law 2/2014 of 14 April on equal treatment and non-discrimination of lesbians, gays, transsexuals, bisexuals and intersexuals in Galicia

34. Law $8 / 2016$, of May 30th, to guarantee the rights of lesbians, gays, trans, bisexuals and intersexes and to eradicate LGTBI phobia

35. Law 2/2016, of March 29, on Identity and Expression of Gender and Social Equality and Non-Discrimination of the Community of Madrid; Law 3/2016, of July 22, on Comprehensive Protection against LGTBiphobia and Discrimination on Grounds of Sexual Orientation and Identity in the Community of Madrid

36. Law 8/2016, of May 27, on social equality of lesbians, gays, bisexuals, transsexuals, transgenders and intersexuals, and on public policies against discrimination based on sexual orientation and gender identity in the Autonomous Community of the Region of Murcia

37. Foral Law $8 / 2017$, of June 19 , for the social equality of LGTBI+ persons

38. Law 14/2012 of 28 June on non-discrimination on the basis of gender identity and recognition of the rights of transsexual persons

39. Law 8/2017, of April 7, of the Generalitat, integral to the recognition of the right to gender identity and expression in the Comunitat Valenciana; Law 23/2018, of November 29, of the Generalitat, on the equality of LGTBI persons.

40. 122/000191 Proposed Law on the legal protection of trans persons and the right to self-determination of trans persons and gender expression in the Valencian Community. Presented by the Confederal Parliamentary Group of Unidos Podemos-En Común Podem-Marea on 22-3-2018.

41. VICENTE PALACIO, Arántzazu, "La existencia de hijos comunes como criterio atributivo de derechos en materia de viudedad: un criterio cuestionable desde la óptica de la prohibición de discriminación (The existence of common children as an attributive criterion of rights in matters of widowhood: a questionable criterion from the perspective of the prohibition of discrimination)", Revista de Seguridad Social (Laborum) $\mathrm{n}^{\circ} 9,2016$.

42. EJC Judgment 41/2013, of 14 February, in resolution of the question of unconstitutionality. In the same vein, in appeals for amparo, STC 55/2013, of 11 March; STC 77/2013, of 8 April; STC 124/2014, of 21 July; STC 188/2014, of 17 November.

43. In relation to the use of the term "de-gendered", in particular with regards to the discussion on Spanish legislation: this term does not exist in the Dictionary of the Royal Spanish Academy (24th edition). I use it here in the same line of the proposal of Professors Martínez Girón and Arufe Varela in relation to the noun "de-gendered" as the Spanish translation of the term "de-gendered", commonly used in the American feminist literature of the 3rd wave, preferable to "non-gendered" because of its radicality given its phonetic similarity (in English) with the adjective "degenerate", a qualifier used pejoratively in relation to the feminist movement and especially the LGBTI movement. In the Spanish case, this radicality is greater because it becomes an identity. The term has been formed from the noun "generation" in its 7th meaning (little used) which is defined as "caste, gender or species" and with the prefix "de" (also non-existent, but in the sense of "non"). See MARTÍNEZ GIRÓN, Jesús y ARUFE VARELA, A., "Deporte profesional de-generado. Un estudio sobre feminismo radical (Professional sport de-gendered. A study on radical feminism)", Barcelona (Atelier), 2017. 